\title{
The Influence of Women Education Level Toward Community Scientific Literacy Improvement in Seberang Kota Jambi
}

\author{
Maisah Maisah \\ Department of Education Management, Tarbiyah and \\ Teaching Faculty \\ State Islamic University of Sulthan Thaha Saifuddin \\ Jambi, Indonesia
}

\author{
Sukarno Sukarno* \\ Department of Physic Education, Tarbiyah and Teaching \\ Faculty \\ State Islamic University of Sulthan Thaha Saifuddin \\ Jambi, Indonesia \\ *sukarno@uinjambi.ac.id
}

\author{
Ahmad Husein Ritong \\ Pascasarjana \\ State Islamic University of Sulthan Thaha Saifuddin \\ Jambi, Indonesia
}

\begin{abstract}
In the 70s, the Education level of women in Seberang Kota Jambi City were relatively low. Women tended to study only the religious education and did not consider general education as an important subject. This tendency resulted in the low science literacy of women in the community. Recently, the education level of a number of women in this community has improved significantly. This study seeks to describe the effect of the improved education level of several women on scientific literacy of the other women in the society. This study used a qualitative and quantitative approach (mixed method). The information is obtained using interviews to 150 women in the community. It was found that the level education of some women has significantly improved the community scientific literacy. Some factors that may contribute to this improvement are: 1). Confidence factors (Religion), 2) economic progress factors, 3) factors of infrastructure development and 4) information factors. As for science literacy, it is generally dominated by literacy levels at the "moderate" level of $43 \%$, "low" level of $35 \%$ and subsequently "high" level of $22 \%$. Based on the literacy tests in the community, it was shown that $58 \%$ were in Functional Literacy, 38\% in Civic literacy, and $6 \%$ in the Cultural Literacy group.
\end{abstract}

Keywords: transformation, women's education, literacy of science

\section{INTRODUCTION}

Understanding the process of education in schools is not only a learning activity between students and their teachers. But how do students have the opportunity to translate and explain the real problems facing themselves in society. Here, education has meaning as an effort to free oneself and free others from oppression and the shackles of ignorance, so that education can truly equip itself in facing real life.
Transformational comes from the word trans (displacement) formational (transformed form), transformed to change something completely and usually in agood way or to transform, which means transforming or transforming something into another different form, for example transforming a vision into reality, or change something potential to actual [1]. Therefore, transformational implies traits that can turn something into another form, for example turning potential energy into actual or achievement motives into real achievements [2].

The term education originally came from the language "Greek", "pedagogies", which means guidance given to children. This term is then translated into English with "education" which means development or guidance. In Arabic this term is often translated as "tarbiyah" which means education. Thus, education means all the efforts of adults in their association with children to lead their physical and spiritual development toward maturity [3]. In addition, the term education also means basic and planned efforts to create a learning atmosphere and learning process so that students actively develop their potential to have religious spiritual strength, self-control, personality, intelligence, noble character, and skills, which are needed by themselves, society, and country [2].

Education is a fundamental aspect in an effort to prepare human resources in the face of the processes and dynamics of people's lives in nation and state amidst plurality. Education is a process that is sustainable, continuous and lasts a lifetime (long life education) in order to realize an adult human, independent and responsible and have faith and fear of the Almighty God [4]. Thus education transformation can be understood as a change, both in form, character, function and 
In addition, scientific literacy can also be understood as a so on as a result of a conscious and planned effort that encourages students to actively develop their potential. Related to the meaning of transforming women's education, it can be understood that the transformation of women's education can be understood as a change, both in the form, nature, function and so on of women as a result of conscious and planned efforts that actively encourage students to develop potential himself.

In the current era of globalization, education has a very broad role, both covering aspects of the economy, culture, politics or social aspects even though it will provide a very open possibility for anyone to compete in each participating country. Free competition like this requires the readiness of each country optimally if you want to be able to continue participating. If not, the country must be prepared to go bankrupt and get out of the competition arena [5].

At present, with the development of science and technology faced with situations that are worrying, challenging, and providing hope. Worrying, because it will allow the loss of joints and norms of life, issues of poverty, natural disasters, health and a number of other issues. Education is faced with the fragility of values, principles, ethics and morals, we are trapped in a circle of development of science and technology. Challenging and giving hope, because these developments also participate in increasing the prosperity and welfare of mankind. The development of science and technology has encouraged the birth of new industries, opened employment, improved relations between countries and so on.

The situation of the people across the city of Jambi, especially for women in the last few years has undergone a change or transformation, both in form, nature and function. Form changes, for example, can be seen from the changes in the form of education itself. The women across the city of Jambi who had previously (several decades ago) tended to choose non-formal and religious education. But now, they tend to choose formal education both general and religious. In terms of the nature of education, previously they chose to "only" complete basic education, but now they have the courage to attend education to the undergraduate level and even the Doctoral level.

The transformation of women's education in the Seberang Kota Jambi area is expected to be in line with the increase in the level or power of literacy of women towards science. Scientific literacy is very important to be mastered by students in relation to the way they understand the environment, health, economics, and other modern society problems that depend on technology and the progress and development of science [6]. Scientific literacy is as the ability to engage with problems related to science, and with scientific ideas, as a reflection of citizens [7]. Scientific literacy is an important thing to master because of its wide application and almost in all fields. Developed countries continue to strive to improve the scientific literacy capabilities of the younger generation in the hope that they can be more competitive, especially in the global workforce [8]. science and understanding of the concepts and processes of science that will enable a person to make a decision with the knowledge he has, and to be involved in state, culture and economic growth. Science literacy can be interpreted as an understanding of science and its application to people's needs [9].

Referring to the current condition of the "global era" the transformation of women's education and scientific literacy for women is a must. So, the shutting down or being exclusive (not literate to science) will be out of date, being open to the risk of losing identity or personality [10]. In other hand, that the future of education and education in the future are two expressions that have interconnected dimensions [11]. The future of education refers to the strategic position of education in the future among other sectors of life, such as economics, politics, law, culture and so on. Meanwhile future education is intended for education policies and practices that must be implemented in connection with the development and empowerment of human resources to enter life in the future, at least in the $21 \mathrm{st}$ century or the third millennium.

Based on a grand tour of the equality of women's education in Seberang Kota Jambi, 75\% of women's education is still low in areas in 1970-1980. But now (in the past three decades), it has experienced a very good transformation. In addition, the level of scientific literacy for women is generally unknown. Therefore, this study focuses on answering the question of how the transformation process of education takes place and what is the level of scientific literacy for women in Seberang Kota Jambi areas? Thus, the purpose of this study is to describe the process of transformation and efforts to improve scientific literacy for women in the Seberang Kota Jambi areas.

\section{RESEARCH METHODS}

In this study, researchers used a qualitative-quantitative approach. A qualitative approach was used to collect data related to the transformation process of education, while a qualitative approach was used to analyse the level of scientific literacy of women in the Seberang Kota Jambi. The method of data collection is done by interviews, document collection and literacy level tests. Interviews are used to search and explore information regarding the transformation of women's education. With this data, the pattern of transformation of women's education can be well described. Assessment of literacy was tested by tests, test results. Based on these results, further analysis of the percentage of literacy level was carried out at three levels, namely, high, medium and low. In addition, based on the literacy level test, further scientific literacy can be divided into three levels [12]. First, functional literacy refers to a person's ability to relate to basic human needs such as food, health and protection. Secondly, civic literacy refers to the ability of a person to participate wisely in the social field regarding issues relating to science and technology, third, cultural literacy that includes awareness of scientific endeavours and the perception that science is the main intellectual activity. 


\section{RESEARCH RESULTS AND DISCUSSION}

\section{A. Transformation of Women's Education in Seberang Kota Jambi Areas in the Last Three Decades}

Seberang Kota Jambi is an area located in the Northern part of the Jambi City area which has an area of $15.70 \mathrm{~km}$ with a maximum temperature of $31 \mathrm{C}$ and is a low land area, because the height of the two sub-districts of Teluk and Pelayangan Sub district is 831 M Seberang Kota Jambi is located north of the Batang Hari River, as for diverse livelihoods, there are farm laborers, Civil Servants, Jambi Batik craftsmen, Fishermen, but the majority are farmers. The condition of the houses of almost all the stages, because the area is prone to flooding, even once every 3 months flooded during the rainy season, so that the Batang Hari river overflowed settlements. Even though it was flooded on the other side the residents brought fortune as it was easy to catch fish and wash down a dirty house.

In relation to education, it can be said to be a powerful tool to make each student be able to sit evenly and stand tall. Through education the sense of class and caste differences can be eliminated, because in the eyes of the law every citizen is the same and must receive the same treatment. In addition, education can also be a vehicle for the state to develop the human resources needed, and can develop themselves according to their potential.

Based on the results of the study, there were no documentation data about the level of education and the number of women's education from 1970 to 1980 in the District Offices of Danau Teluk and Kecamatan Pelayangan. This was confirmed by an explanation from the Head of the Village Head, which had the initials AM, that the data on education in 1970-1980 no longer existed. In 1970, many women were not allowed to go out of their homes to go to school, and at that time women in Seberang Kota Jambi learned more about studying Islam, coming to the home of the Qur'an teachers of the Apart from that, it is also inseparable from the opinions of parents and religious scholars at that time, that public schools were infidels.

Another opinion was also expressed by one of the community leaders who had the initials $\mathrm{KD}$ saying that in 1970-1980, women's education at that time was $75 \%$ low, because women were not allowed to go to school. Women are more at home, taking care of the household for those who are married and those who are not married are told to help their mothers at home. Education only teaches religion with the teacher reciting after " $B a$ 'da Mangrib". At that time women also had more marriages at an early age. Because there are no regulations that regulate the absence of early marriage. However, the more priority is the education of boys, both religious education and there is also general education.

Regarding the education of women in the traditional era of 1970-1980, it was difficult for independent research to be independent and very limited. This is inseparable from the myths raised by some people that the education of women is not of high importance. The most important thing is that women are more priority to take care of the household or just stay home. In accordance with the results of interviews, researchers with several female figures from Jambi Seberang Kota, such as one with the initials MD, stated that in the past the education of women was not so important. Calling on women is not the duty to earn a living, but is assigned to take care of the household as well as the husband's career supporters, coupled with traditional rules that are still very strong. In addition, women's regulations are increasingly limited by values in adat which regulate how appropriate behaviour is for women at that time. Therefore, the education of women does not need to be high, just elementary school graduates are enough, even the majority of women are educated when they don't finish school.

Another statement was also stated by one of the women with the initials SA who stated that women's education was in the area across from the city of Jambi. According to him, most women are not allowed to go to school. Because of the opinion of parents at that time in Seberang Kota Jambi, there were still strong local customs that did not allow girls to go to school. For mythical reasons, it was stated that the highest level of education for women would be in the kitchen too. This means that women's education is considered to be unable to develop like a boy. Therefore, girls in 1980 were married more at an early age, if the girl had found her soul mate, and there was also an arranged marriage.

Another statement was also stated by a woman whose initials in the US suggested women's education in 1980-1990 was still very low, which at that time, parents' thinking was still very traditional towards education for girls. Therefore, there are only a few parents whose thoughts have led to progress that allows their daughters to continue their education to the higher level.

Based on the results of interviews with several women in Seberang Kota Jambi, it can be understood that the education of women in traditional times was indeed low-rated and not considered, this was caused by the education of parents who were still low, resulting in a less extensive thinking about education for their daughters, even though the area is adjacent to Jambi City which is very close to educational facilities that are already so advanced. If we pay close attention to the education of Seberang Kota Jambi women, it is not so much different from the education of women in rural areas. There are several factors that caused women in 1970-1980 to be poorly educated according to the results of the interviews of researchers with one of the mothers whose initials MD said:

1) Religious factors: In the 1980s and down, it could be said that almost all Seberang Kota Jambi people made religious education the only choice for their children's education. This is related to the views of the general public figures that have been formed since the Dutch colonial era, which said that public education is infidel education. This view is one reason parents do not want to send their children to general education, especially girls. Therefore, there is no other choice for the people of Seberang Kota Jambi, aside from including their children's school, religious education. 
demanding knowledge of the content of science, which is then called content knowledge. The second and third competencies, however, require more than just knowledge of what is known. Instead, it depends on an understanding of how scientific knowledge is formed and the level of trust it has [13]. With the state of scientific literacy as shown in Table 1 above, the three competencies above are not fully owned by regional women across from the city of Jambi.

Science literacy can be divided into three levels. First, functional literacy refers to a person's ability to relate to basic human needs such as food, health and protection. Second, civic literacy refers to the ability of a person to participate wisely in the social field regarding issues relating to science and technology, third, cultural literacy which includes awareness of scientific endeavour and the perception that science is the main intellectual activity.

In general, women's literacy in the Seberang Kota Jambi area can be categorized as Functional Literation type. The other literacy types are Civic and Cultural literacy (Table 2). Functional literacy which refers to a person's ability to relate to basic human needs such as food, health and protection. Thus awareness of basic human needs can be understood by women in the area. This fact is supported by information/data from community health centres (such as Puskesmas and Posyandu) that there has been an increase in the improvement of health services for women.

TABLE II. THE TyPES OF LITERACY FOR WOMEN SEBERANG KotA JAMBI

\begin{tabular}{|l|l|l|l|}
\hline \multicolumn{1}{|c|}{ Type of scientific literacy } & \multirow{1}{*}{$\begin{array}{c}\text { Total } \\
\text { Respondent }\end{array}$} & Total & $\begin{array}{c}\text { Percentage } \\
(\mathbf{\%})\end{array}$ \\
\cline { 1 - 1 } Functional Literacy & \multirow{3}{*}{150} & 87 & 58 \\
\cline { 1 - 1 } Civic Literacy & & 54 & 36 \\
\cline { 1 - 1 } Cultural Literacy & 9 & 6 \\
\hline
\end{tabular}

In addition, the good level of functional literacy for women is also evident from the increase in women's activities related to food problems and protection of women. This is indicated by data (interviews) from community leaders and security officials (police) that there has been a decline in the number of domestic violence (women as victims), and there has been an increase in women's involvement in women's protection commissions. In addition, awareness of food by women has also increased in the past three decades, this can be seen from the data of job seekers, that women in areas across Jambi city have increased. These women work in various sectors (education, agriculture, trade and government). So, the literacy and low-literate education are both personal characteristics of hard working, upstanding citizens [14].

Secondly, civic literacy refers to the ability of a person to participate wisely in the social field regarding issues relating to science and technology. In this second type of literacy, women in the Seberang Kota Jambi area are also quite good. There are around $36 \%$ of the total respondents having this second type of literacy. Thus it can be understood that there is active involvement by women in the fields of science and technology. This can be seen from the data / information that there has been 


\section{REFERENCES}

an increase in the use of science and technology by women, mainly related to electronic technology.

Third, cultural literacy which includes awareness of scientific endeavour and the perception that science is the main intellectual activity. At this level there are only $6 \%$ of the total respondents who have cultural literacy awareness. It can be seen that women's involvement in science activities is still low. Based on the data obtained, it is known that the women in Seberang Kota Jambi are more likely to seek knowledge in the field of social sciences, so that the scientific culture becomes rather slow to develop among women.

Based on the explanation above, it can be seen that there is a connection between the level of scientific literacy and the transformation of education among women in the Seberang Kota Jambi area. It can be assumed that one of the contributors is still the slow process of transforming education into a cause of the low level of scientific literacy, especially on cultural literacy.

\section{CONCLUSIONS}

Based on the research findings, it can be concluded that the education transformation among women in the last three years has increased. This is caused by several factors including: a) an increase in the economy, b) a change in mind-set, c) an increase in the development of transformation infrastructure that can facilitate the access of the community people to develop, d) the establishment of public institutions that can bring up the horizons of thinking more broadly, e) easier access to education. In general, the level of scientific literacy among women in areas across Jambi city is dominated by Functional literacy followed by civic literacy and finally cultural literacy. This requires that women have experienced positive changes in relation to scientific literacy.
[1] U. Husaini, Manajemen, Teori Praktik dan Riset Pendidikan, Jakarta: Bumi Aksara, 2008

[2] Haryanto, Pengertian pendidikan menurut para akhli, 2012,[Online] Retrieved from: http://belajarpsikologi. com/pengertianpendidikanmenurut-ahli/ diakes pada tanggal 9 april 2017

[3] D. Zakiah, Ilmu Pendidikan Islam, Jakarta: Bumi Aksara, 1994, p. 1.

[4] Zainuddin, Reformasi Pendidikan, Yokyakarta, Pustaka pelajar, 2008.

[5] Sam M. Chan, Kebijakan Pendidikan era Otonomi Daerah, Jakarta: Raja Grafindo Persada, 2005, p. 137.

[6] Sulistiawati, Analisa Pemahaman Literasi Sains Mahasiswa yang Mengambil Mata Kuliah IPA Terpadu Menggunakan Contoh Soal PISA 2009, Sainteks, vol. 12, no. 1, pp. 21-40, 2015.

[7] PISA, PISA 2015 Draft Science Framework, 2015 [Online]. Retrieved from: http://www.oecd.org/pisa/pisaproducts/Draft PISA 2015 Science Framework.pdf.

[8] N.S. Erviani, Pengaruh Pembelajaran Interactive Demonstration Terhadap Peningkatan Kemampuan Literasi Sains Dan Sikap Ilmiah Siswa Smp Pada Materi Ekosistem (Doctoral dissertation, Universitas Pendidikan Indonesia), 2015.

[9] A.A. Sudiatmika, Istri Rai, _Development Of Scientific Literacy Instrument Test For Junior High School Student In The Context Of Balinese Culture‘, Repository Perpustakaan Kemendikbud, 2018.

[10] A. Abd, Rahman, Pendidikan Islam dan Tantangan Globalisasi, Jogjakarta, Ar-Ruzz Media, 2004, p. 8.

[11] S. Syaukani, Pendidikan Paspor Masa Depan, Jakarta: IKPI, 2006, p. 79.

[12] Y. Shwartz, R. Ben-Zvi, and A. Hofstein, "The use of scientific literacy taxonomy for assessing the development of chemical literacy among high-school students," Chemistry Education Research and Practice, vol. 7, no. 4, pp. 203-225, 2006.

[13] H. Firman, Analisis Literasi Sains Berdasarkan Hasil PISA Nasional Tahun 2006. Jakarta: Pusat Penilaian Pendidikan Balitbang Depdiknas, 2007.

[14] R. St Clair and J.A. Sandlin, "Incompetence and intrusion: On the metaphorical use of illiteracy in US political discourse," Adult Basic Education, vol. 14, no. 1, pp. 45, 2004 